\title{
The Effect of Anemia and the Goal of Optimal HbA1c Control in Diabetes and Non-Diabetes
}

\author{
Prakash C. Katwal ${ }^{1}$, Srood Jirjees ${ }^{2}$, Zin Mar Htun ${ }^{1}$, Israa Aldawudi ${ }^{3}$, Safeera Khan ${ }^{1}$ \\ 1. Internal Medicine, California Institute of Behavioral Neurosciences and Psychology, Fairfield, USA 2. Neurology, \\ California Institute of Behavioral Neurosciences and Psychology, Fairfield, USA 3. Radiology, California Institute of \\ Behavioral Neurosciences and Psychology, Fairfield, USA
}

Corresponding author: Prakash C. Katwal, pck.prapd@gmail.com

\begin{abstract}
Hemoglobin A1c (HbA1c) is the gold standard for the diagnosis of diabetes; however, many clinical conditions affect the HbA1c level, including anemia. And, the most common causes of anemia worldwide include iron deficiency anemia (IDA). We performed a systematic search using different combinations of MeSH words from the electronic database for the last 10 years (2011 to 2020). Articles included in the study were observational, randomized controlled trial (RCT), and review/systematic review. A total of 18 articles were included in the study. The majority of the studies showed the association between hemoglobin $(\mathrm{Hb})$ and HbA1c. Large-scale studies showed that the HbA1c level increases in IDA and some studies showed its correction after the treatment with oral iron supplementation. Our study indicates the need for screening for anemia in patients before commencing the treatment of diabetes diagnosed via the HbA1c level. Furthermore, anemia should be corrected before setting the treatment goal of optimal HbA1c control, especially when the level is in the diagnostic threshold. Also, the purpose of strict HbA1c control is not recommended in the anemic patient before it is corrected. However, further large-scale interventional studies are needed to know precisely the goal of optimal HbA1c control in diabetic and non-diabetic individuals.
\end{abstract}

Categories: Endocrinology/Diabetes/Metabolism, Internal Medicine, Hematology

Keywords: hba1c, diabetes, hemoglobin, anemia, iron deficiency anemia (ida)

\section{Introduction And Background}

Anemia is defined as a reduction in the oxygen-carrying capacity of blood and measured by the cut-off value of $\mathrm{Hb}$ level $<12.0 \mathrm{mg} / \mathrm{dl}$ in adult non-pregnant women and $<13.0 \mathrm{mg} / \mathrm{dl}$ in adult men [1]. The prevalence of anemia is $32.9 \%$ worldwide, and among many causes of anemia, iron deficiency anemia (IDA) is the most common cause [2].

Received 05/05/2020 Review began 05/16/2020 Review ended 06/03/2020 Published 06/03/2020

\section{(c) Copyright 2020}

Katwal et al. This is an open access article distributed under the terms of the Creative Commons Attribution License CC-BY 4.0., which permits unrestricted use, distribution, and reproduction in any medium, provided the original author and source are credited.
Diabetes mellitus (DM) is a clinical syndrome occurring due to an absolute or relative deficiency of insulin, leading to abnormal carbohydrate metabolism. It is manifested clinically as hyperglycemia and is broadly classified as Type I and Type II DM, of which >85\% disease burden is due to Type II [3]. The diagnosis of DM is made on the basis of fasting, two-hour postprandial, random blood sugar, and HbA1c. In euglycemic person $\mathrm{HbA} 1 \mathrm{c}$ is < 5.5\%, impaired glucose tolerance $5.6 \%-6.5 \%$ and $>6.5 \%$ is considered diabetic [4].

Hemolytic anemia leads to the reduced lifespan of red blood cells (RBC), and IDA prolongs it; as a result, there occurs the discrepancy in hemoglobin A1c (HbA1c) [5]. HbA1c is the product of the non-enzymatic chemical reaction of $\mathrm{Hb}$ with glucose. It reflects the average amount of blood glucose in the past two to three months [6]. HbA1c is an important tool to assess glycaemic control, and its regular monitoring and strict control reduce the onset and progression of wide varieties of diabetic-related complications [7].

Furthermore, HbA1c is one of the gold standard tests' in the diagnosis of DM and monitoring of long-term blood glucose levels [8], in anemia because these causes can lead to erroneous increase or decrease in HbA1c leading to misinterpretation of the disease condition. So, the significance of Hb value in serial monitoring of $\mathrm{HbA1c}$ and the cut-off value of $\mathrm{Hb}$ below which $\mathrm{HbA1c}$ cannot be considered as important diagnostic and monitoring tools in diabetes is still a mystery [6].

There has been a controversy for the use of HbA1c as a diagnostic tool in anemia. As a result, we aim to find the effect of anemia and the goal of optimal HbA1c control in diabetes and non-diabetes from the available evidence.

\section{Review}

\section{Methods}

We performed a systematic search on PubMed, PMC, and Google scholar and searched for the studies published in the last 10 years. Keywords used in different combinations were: "HbA1c", "Diabetes and 


\section{Cureus}

HbA1c" "Diabetes and Anemia," "HbA1c and Anemia and Diabetes," as shown in Table 1. All articles published in English between this period were considered for review. Search engines like "Google,"

"Medscape," "UpToDate" were also used to find the related articles. Reference lists of all the articles were manually checked to identify studies not found through electronic searching. Quality checks were not performed for all studies.

Approval of an ethics committee was not required.

\begin{tabular}{|c|c|c|c|}
\hline Keyword/MeSH & Date & Databased used & No of paper/result \\
\hline HbA1C & 05/03/2020 & PubMed & 53,071 \\
\hline Diabetes and $\mathrm{HbA1C}$ & 05/03/2020 & PubMed & 48,668 \\
\hline Diabetes and Anemia & 05/03/2020 & PubMed & 6,540 \\
\hline HbA1c and Anemia and Diabetes & 05/03/2020 & PubMed & 380 \\
\hline HbA1c and Anemia and Diabetes & 05/03/2020 & PMC & 4,022 \\
\hline HbA1c and Anemia and Diabetes & 05/03/2020 & Google Scholar & 20,400 \\
\hline
\end{tabular}

\section{TABLE 1: Electronic search results}

HbA1c, hemoglobin A1c

\section{Inclusion and exclusion criteria}

All the articles relevant to the topic were searched in different databases. Only articles published in English medium with full text between 2011 to 2020 and articles from all the geographical locations were included. All types of studies were included except animal studies.

\section{Result}

The database searches identified 380 related articles out of which 316 articles were excluded based on title and/or abstract, which were not relevant to our study. Out of the remaining 64 full-text articles, 46 were excluded after further reading, and 18 articles were approved for the study. The main reason for exclusion was incomplete data and/or not meeting the inclusion criteria. Included articles had at least one measurement of HbA1c and hemoglobin by any method; however, this rule was not applied for the review articles. No additional articles were identified via reviews of reference lists (Figure 1) 


\section{Cureus}

\section{Total $\mathrm{N}=380$}

Exclusion based on title and/or abstract $\mathrm{N}=316$

\section{Full-text articles \\ reviewed $\mathrm{N}=64$}

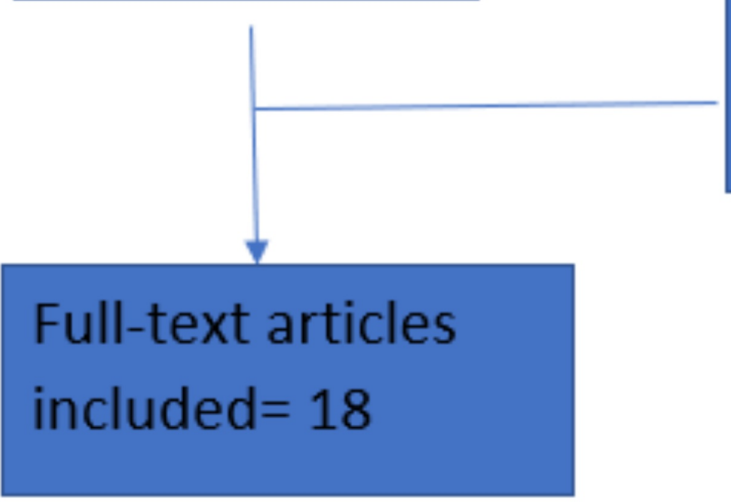

Exclusion based on full text $\mathrm{N}=46$

\section{FIGURE 1: Flow chart of the search strategy}

$\mathrm{N}$, number of articles

\section{Discussion}

Various studies have been conducted to gauze the relationship between anemia and HbA1c. More studies were directed towards IDA. The effect of IDA on the HbA1c level was first studied by two American researchers Horton and Huisman, in 1965 [9]. Ongoing studies have been done since then, which are out of the scope of this review article and can be found in various journals. We have tried to review related articles from 2011 to till date, which are depicted in Table 2 and Table 3.

\begin{tabular}{|c|c|c|c|c|c|c|}
\hline Source & $\begin{array}{l}\text { Sample } \\
\text { size }\end{array}$ & $\begin{array}{l}\text { Age } \\
\text { group }\end{array}$ & Study type & HbA1c (\%) & Hb level & Result \\
\hline $\begin{array}{l}\text { Solomon } \\
\text { et al. } 2019 \\
\text { [10] }\end{array}$ & 174 & $\begin{array}{l}>18 \\
\text { years }\end{array}$ & $\begin{array}{l}\text { Cross- } \\
\text { Sectional }\end{array}$ & $\begin{array}{l}\text { IDA: } 6.18+/-1.57 \\
\text { Non-IDA: } 7.74+/-1.81 \\
(P<0.05)\end{array}$ & $\begin{array}{l}\text { IDA: } 9.97+/-2.04 \\
\text { Non-IDA: } \\
15.17+/-1.21 \\
(P<0.05)\end{array}$ & $\begin{array}{l}\text { HbA1c is significantly lower in } \\
\text { diabetic with IDA compared with non- } \\
\text { IDA }(P<0.05)\end{array}$ \\
\hline $\begin{array}{l}\text { Kalairajan } \\
\text { et al. } 2019 \\
\text { [11] }\end{array}$ & $\begin{array}{l}\text { Case: } \\
120 ; \\
\text { Control: } \\
120\end{array}$ & $\begin{array}{l}18-60 \\
\text { years }\end{array}$ & $\begin{array}{l}\text { Prospective } \\
\text { Interventional }\end{array}$ & $\begin{array}{l}\text { IDA: } 4.62+/-0.30 \\
\text { Non-IDA: } 5.45+/-0.28 \\
\text { (P<0.001). After } \\
\text { correction: HbA1c: } \\
5.82+/-0.32(P<0.001)\end{array}$ & $\begin{array}{l}\text { IDA: } 6.8+/-1.08 \\
\text { Non-IDA: } 13.4+/- \\
0.35 \text { (P<0.001). } \\
\text { After correction: } \\
12.7+/-0.44 \\
(\mathrm{P}<0.001)\end{array}$ & $\begin{array}{l}\text { The significant correlation observed } \\
\text { between } \mathrm{Hb} \text { and } \mathrm{HbA} 1 \mathrm{c} \text { level } \\
\text { (coefficient of correlation: } 0.26 \text {; } \\
\mathrm{P}<0.01 \text { ) }\end{array}$ \\
\hline Urrec & 661 & $>$ & ;- & $\begin{array}{l}\text { Female }>50 \text { years: } \\
7.0+/-1.5<50 \text { years: } \\
6 / 3+/-1.3 . \text { Male: }>50\end{array}$ & $\begin{array}{l}\text { LID: >120g/L, } \\
\text { IDA: male: <130 }\end{array}$ & relation between $\mathrm{HbA} 1 \mathrm{c}$ \\
\hline
\end{tabular}




\section{Cureus}

\begin{tabular}{|c|c|c|c|c|c|c|}
\hline 2018 [15] & & years & Sectional & $\begin{array}{l}\text { years: } 7.0+/-1.6<50 \\
\text { years: } 6.7+/-1.6\end{array}$ & $\begin{array}{l}\text { g/L, female: }<120 \\
g / L\end{array}$ & and IDA \\
\hline $\begin{array}{l}\text { Madhu et } \\
\text { al. } 2017 \\
\text { [16] }\end{array}$ & 122 & $\begin{array}{l}20-70 \\
\text { years }\end{array}$ & Case-Control & $\begin{array}{l}\text { Case: } 5.5+/-0.7 \\
\text { Control: } 4.9+/-0.5 \\
(P<0.001)\end{array}$ & $\begin{array}{l}\text { Case: } 73.9+/- \\
\text { 12.2. Control: } \\
\text { 134.3+/-13.2 } \\
(P<0.001)\end{array}$ & $\begin{array}{l}\text { Significantly higher HbA1c in IDA P } \\
<0.001 \text { and significant improvement in } \\
\text { HbA1c level after oral iron } \\
\text { supplementation }\end{array}$ \\
\hline $\begin{array}{l}\text { Alsayegh } \\
\text { et al. } 2017 \\
\text { [12] }\end{array}$ & 1580 & $\begin{array}{l}18-71 \\
\text { years }\end{array}$ & $\begin{array}{l}\text { Cross- } \\
\text { Sectional }\end{array}$ & $\begin{array}{l}>7 \text { anemia }(80.7 \%) \\
\text { non-anemia }(80.4 \%) \\
<7 . \text { Anemia }(19.3 \%) \\
\text { non-anemia }(19.6 \%)\end{array}$ & $\begin{array}{l}\text { Anemia: male: } \\
<130 \mathrm{~g} / \mathrm{L} \text {, female: } \\
<120 \mathrm{~g} / \mathrm{L}\end{array}$ & $\begin{array}{l}\text { Higher prevalence of anemia in the } \\
\text { diabetic patient }(\mathrm{P}<0.001) \text {. } \\
\text { Furthermore, diabetic peripheral } \\
\text { neuropathy and diabetic foot were } \\
\text { commonly associated with anemia. } \\
\text { However, there was no association } \\
\text { between } \mathrm{HbA1c} \text { and } \mathrm{Hb}(\mathrm{P}=0.887)\end{array}$ \\
\hline $\begin{array}{l}\text { Inada and } \\
\text { Koga } \\
2017[17]\end{array}$ & 35 & $\begin{array}{l}\text { Non- } \\
\text { IDA } \\
59.0+/- \\
7.8 . \\
\text { IDA: } \\
59.1+/- \\
2.2 \\
\text { years }\end{array}$ & Case-Control & $\begin{array}{l}\text { IDA: } 6.2+/-0.4 \% . \\
\text { Non-IDA: } 5.7+/-0.3 \\
(P=0.003)\end{array}$ & $\begin{array}{l}\text { Without anemia: } \\
\text { 139+/-0.8. With } \\
\text { IDA: } 11.1+/-0.9 \\
(\mathrm{P}<0.0001)\end{array}$ & $\begin{array}{l}\text { HbA1c level is higher in } \\
\text { gastrectomized subjects with IDA } \\
\text { than non-IDA ( } P=0.003)\end{array}$ \\
\hline $\begin{array}{l}\text { Esfahani } \\
\text { et al. } 2017 \\
\text { [18] }\end{array}$ & $\begin{array}{l}90(45 \\
\text { cases, } 45 \\
\text { control) }\end{array}$ & $\begin{array}{l}18-65 \\
\text { years }\end{array}$ & RCT & $\begin{array}{l}\text { Pre: case } 7.59+/- \\
\text { 1.16, control: } 7.40+/- \\
\text { 1.01. Post: case: } \\
6.80+/-0.85 \text {, control: } \\
7.14+/-0.95(P<0.001)\end{array}$ & $\begin{array}{l}\text { Pre: case: } \\
11.52+/-0.86, \\
\text { control: } 11.3+/- \\
0.73 . \text { Post: case: } \\
13.71+/-1.37 \text {, } \\
\text { control: } 11.6+/- \\
1.24(P<0.001)\end{array}$ & $\begin{array}{l}\text { Significant improvement in the HbA1c } \\
\text { level after treatment with iron therapy } \\
\text { in anemia patient with IDA and Type II } \\
\text { diabetes }\end{array}$ \\
\hline $\begin{array}{l}\text { Silva et } \\
\text { al. } 2016 \\
{[19]}\end{array}$ & 122 & $\begin{array}{l}18-77 \\
\text { years }\end{array}$ & Case-Control & $\begin{array}{l}\text { Anemia: } 5.6+/-0.4 \\
\text { (HPLC method) } \\
5.7+/-0.4 \\
\text { (Immunoturbidimetry } \\
\text { Method). No Anemia: } \\
5.3+/-0.4(\text { HPLC } \\
\text { Method) } 5.3+/-0.3 \\
\text { (Immunoturbidimetry } \\
\text { Method) }(P<0.001)\end{array}$ & $\begin{array}{l}\text { Mild: Male: } 11-13 \\
\mathrm{mg} / \mathrm{dl} . \text { Female: } \\
11-12 \mathrm{mg} / \mathrm{dl} . \\
\text { Moderate: } 8-11 \\
\mathrm{mg} / \mathrm{dl} . \text { Severe: }<8 \\
\mathrm{mg} / \mathrm{dl}\end{array}$ & $\begin{array}{l}\text { IDA affects HbA1c value, which } \\
\text { depends on the severity of anemia. In } \\
\text { cases of mild anemia, there is a } \\
\text { minimal effect in HbA1c and can be } \\
\text { used as a diagnostic tool for diabetes }\end{array}$ \\
\hline $\begin{array}{l}\text { Hong et } \\
\text { al. } 2015 \\
{[20]}\end{array}$ & 10665 & $\begin{array}{l}>19 \\
\text { years }\end{array}$ & $\begin{array}{l}\text { Cross- } \\
\text { Sectional }\end{array}$ & $\begin{array}{l}\text { No Anemia: } 5.59+/ \\
0.01 . \text { Non-IDA: } \\
5.44+/-0.03 . \text { IDA: } \\
5.70+/-0.02 \text { (P<0.001) }\end{array}$ & $\begin{array}{l}\text { No anemia: } \\
\text { 14.4+/-0.1. Non- } \\
\text { IDA: } 12.3+/-0.1 \text {. } \\
\text { IDA: } 11.5+/-0.1 \\
(P<0.001)\end{array}$ & $\begin{array}{l}\text { No significant difference in the HbA1c } \\
\text { level between IDA and non-IDA. } \\
\text { However, in euglycemic and } \\
\text { prediabetic, HbA1c is significantly } \\
\text { higher in IDA compared to non-IDA }\end{array}$ \\
\hline $\begin{array}{l}\text { Christy et } \\
\text { al. } 2014 \\
\text { [21] }\end{array}$ & 120 & $\begin{array}{l}>18 \\
\text { years }\end{array}$ & Case-Control & $\begin{array}{l}\text { IDA: } 6.87+/-1.4, \text { Non- } \\
\text { IDA: } 5.65+/-0.69\end{array}$ & $\begin{array}{l}\text { Low Hb: Male } \\
<12 \mathrm{gm} \% \text {, female } \\
<11 \mathrm{gm} \%\end{array}$ & $\begin{array}{l}\text { A positive correlation between IDA } \\
\text { and increase } \mathrm{HbA} 1 \mathrm{c} \text { level, especially } \\
\text { in controlled diabetes women and } \\
\text { individuals with fasting plasma } \\
\text { glucose } 100-126 \mathrm{mg} / \mathrm{dl}\end{array}$ \\
\hline $\begin{array}{l}\text { Shanthi et } \\
\text { al. 2013 } \\
\text { [22] }\end{array}$ & $\begin{array}{l}\text { Case: } 50 . \\
\text { Control:50 }\end{array}$ & $\begin{array}{l}43.52+1- \\
7.79\end{array}$ & Case-Control & $\begin{array}{l}\text { In IDA: } 7.6+/-0.5 \% \\
\text { Non-IDA: } 5.5+/-0.8 \% \\
(P<0.001)\end{array}$ & $\begin{array}{l}\text { IDA: } 10.6+/-1.4 . \\
\text { Non-IDA: } 13.4+/- \\
0.96 \%\end{array}$ & $\begin{array}{l}\text { The author concluded that there is a } \\
\text { significant positive correlation } \\
\text { between HbA1c and IDA. So, it is } \\
\text { important to screen for IDA before } \\
\text { starting the treatment for diabetes }\end{array}$ \\
\hline $\begin{array}{l}\text { Ford et } \\
\text { al. } 2011 \\
{[14]}\end{array}$ & 8296 & $\begin{array}{l}>=20 \\
\text { years }\end{array}$ & $\begin{array}{l}\text { Cross- } \\
\text { Sectional }\end{array}$ & $\begin{array}{l}\text { Mean } \mathrm{HbA} 1 \mathrm{c} 5.28 \% \\
\text { (in } \mathrm{Hb}<100 \mathrm{~g} / \mathrm{L}) \& \\
5.72 \% \text { (In Hb } \\
>170 \mathrm{~g} / \mathrm{L}) . \text { Adjusted } \\
\text { mean HbA1c, in IDA: } \\
5.56 \% . \text { Non-IDA: } \\
5.46 \%(\mathrm{P}=0.095)\end{array}$ & $\begin{array}{l}\text { Prevalence of } \\
\text { anemia IDA: } \\
2.3+/-0.2 \% \text { Non- } \\
\text { IDA: } 3.2+/-0.3 \% \text {. } \\
\text { Normal Hb with } \\
\text { IDA: } 4.4+/-0.3 \% \text {. } \\
\text { Normal Hb and } \\
\text { normal Iron: }\end{array}$ & $\begin{array}{l}\text { A significant positive correlation } \\
\text { between } \mathrm{Hb} \text { concentration and } \mathrm{HbA} 1 \mathrm{C} \\
\text { concentration. Furthermore, caution } \\
\text { should be made in diagnosing } \\
\text { diabetes in patients with anemia who } \\
\text { are close to the diagnostic threshold } \\
(6.5 \% \& 5.7 \%) \text { and need another } \\
\text { method or retesting for diagnosis }\end{array}$ \\
\hline
\end{tabular}




\section{Cureus}

\begin{tabular}{|c|c|c|c|c|c|c|}
\hline \multirow[b]{2}{*}{$\begin{array}{l}\text { Villar et al. } \\
2011 \text { [13] }\end{array}$} & \multirow[b]{2}{*}{89} & \multirow[b]{2}{*}{$\begin{array}{l}18-80 \\
\text { years }\end{array}$} & \multirow[b]{2}{*}{ RCT } & & \multicolumn{2}{|l|}{$90.1+/-0.4 \%$} \\
\hline & & & & $\begin{array}{l}\text { Sub-normal: } 7.5+/- \\
\text { 1.3. Normal: } 7.6+/- \\
\text { 1.4 }(P=0.73)\end{array}$ & $\begin{array}{l}\text { Sub-normal Hb: } \\
\text { 110-129. Normal: } \\
130-149 \mathrm{gm} / \mathrm{L}\end{array}$ & $\begin{array}{l}\text { HbA1c did not vary significantly with } \\
\text { anemia correction in chronic kidney } \\
\text { disease }(P>0.05)\end{array}$ \\
\hline
\end{tabular}

\section{TABLE 2: Observational/RCT studies}

IDA, iron deficiency anemia; HbA1c, hemoglobin A1c; Hb, hemoglobin; LID, latent iron deficiency; RCT, randomized controlled trials; HPLC, highperformance liquid chromatography

\begin{tabular}{|c|c|c|}
\hline Source & Study type & Result \\
\hline Guo et al. 2019 [6] & Review & Effects of IDA on HbA1c are multifactorial and multi-dimensional however \\
\hline $\begin{array}{l}\text { Naqash and Bader } \\
2018 \text { [23] }\end{array}$ & Review & $\begin{array}{l}\text { HbA1c level is dependent on erythrocyte turnover. So, in IDA HbA1c level increased. However, } \\
\text { the clinical data is insufficient }\end{array}$ \\
\hline $\begin{array}{l}\text { English et al. } \\
2015[7]\end{array}$ & $\begin{array}{l}\text { Systematic } \\
\text { Review }\end{array}$ & In IDA HbA1c level falsely increase while in non-IDA, it may decrease \\
\hline $\begin{array}{l}\text { Ahmad and Rafat } \\
2013[24]\end{array}$ & $\begin{array}{l}\text { Review of } \\
\text { Study }\end{array}$ & $\begin{array}{l}\text { People who are in the diagnostic threshold of diabetes, another method of diagnostic modalities, } \\
\text { are required to diagnose in anemia patients }\end{array}$ \\
\hline Weykamp 2013 [5] & Review & $\begin{array}{l}\text { In anemia due to chronic disease, HbA1c is low due to decreased RBC survival, but in IDA, it is } \\
\text { spuriously high }\end{array}$ \\
\hline \multicolumn{3}{|c|}{ TABLE 3: Review articles and their conclusions } \\
\hline \multicolumn{3}{|c|}{ HbA1c, hemoglobin A1c; IDA, iron deficiency anemia } \\
\hline
\end{tabular}

In 2019, Solomon et al. showed mean Hb, hematocrit, and red cell indices were low as expected in the IDA group [10]. His study revealed that this group had a much lower HbA1c level than the non-IDA group. Therefore, monitoring the diabetic patient with only the HbA1c level should be done with caution. This finding was consistent with an interventional study among 120 subjects by Kalairajan et al. in 2019 [11]. It showed that IDA leads to a decrease in HbA1c level with a subsequent rise in HbA1c level with its correction. This showed a positive correlation between $\mathrm{Hb}$ and HbA1c in IDA before treatment; however, no correlation was observed after correction of anemia by oral iron supplementation for three months. The author in this study acclaims that this was one of the few articles done in the Indian subcontinent where the cause of IDA is nutritional. They also claim that the study was unique and encompasses a wide variety of race and ethnic groups and people of low socio-economic status in that location.

These two studies were contradictory to other studies. As other studies have either failed to find the association between two or the association was reversed. An observational study conducted by Alsayegh et al. in 2017 showed a high prevalence of anemia in diabetes patients (female>male) predominantly more in people with diabetes complications [12]. However, it showed no association between HbA1c and anemia in both males and females. The author further added the need for early diagnosis and prompt treatment of anemia in diabetes patients as it was associated with grave complications of diabetes. The previously published study also supported this finding. The RCT by Villar et al. in patients with Type II diabetes and chronic kidney disease divided the subjects into sub-normal $\mathrm{Hb}(110-129 \mathrm{~g} / \mathrm{L})$ and normal $\mathrm{Hb}(130-149 \mathrm{~g} / \mathrm{L})$ were given iron and/or erythropoietin stimulating agent (ESA) for correction of anemia for 6,12 18, 24 months and HbA1c did not vary significantly $(\mathrm{P}=0.73)$ with correction of anemia [13]. This diversion from the finding in the literature could be accredited to the type of anemia being non-IDA.

Ford et al. had a cross-sectional study of 8,296 patients and found a significant positive correlation between $\mathrm{Hb}$ concentration and HbA1c concentration [14]. However, the HbA1c was found to be higher in IDA patients, and HbA1c concentration in IDA patients was similar to non-IDA patients. This slight variation in the finding can be attributed to the positive association between hemoglobin and $\mathrm{HbA} 1 \mathrm{c}$ being counterbalanced by a negative association between HbA1c concentration and iron profile. Furthermore, the author has warned that caution should be made in diagnosing diabetes in patients with anemia who are close to the diagnostic threshold and need another method or retesting for diagnosis. 
The majority of findings we observed were contradictory to the above findings. A study by Urrechaga in 2018 divided the Type II diabetes patient according to iron status as normal, latent iron deficiency (LID) and IDA and the result showed a non-homogenous increase in the HbA1c values in both latent and apparent iron deficiency anemia in both genders and the age groups above and below 50 years regardless of fasting plasma glucose [15]. The finding of this study was comparable with the previous study by Shanthi et al. [22]. The authors further recommend screening for IDA before commencing treatment in diabetes. Similarly, a study conducted a year before by Madhu et al. in 122 patients also showed comparable findings [16]. Besides, it also showed that in such subjects, the HbA1c level dropped after oral iron supplementation for three months from 5.51+/-0.696 to post-treatment 5.044+/-0.603 with P-value <0.001. Seventy percent of IDA patients of this study were prediabetic, who became euglycemic after iron therapy. This study has similar findings with previous studies by Esfahani et al. [18]. Indirectly this study supports the suggestion of the large survey of Ford et al. to take caution in diagnosing diabetes in IDA patients with threshold HbA1c [14].

Hong et al. have tried to find out the significance of HbA1c as a screening tool in diabetes and prediabetes cases with IDA [20]. The author had compared no anemia, non-IDA, and IDA, and found HbA1c as 5.59+/$0.01,5.44+/-0.03$, and $5.70+/-0.02$, respectively $(\mathrm{P}<0.001)$. They have further added that the presence of IDA affected the HbA1c distribution $>=5.7 \%$ (the cut-off value for impaired glucose tolerance, IGT) and $>=6.1 \%$ (Korean cut-off value for diabetes) but not in $>=6.5 \%$ (WHO cut-off value for diabetes). So, IDA can significantly increase in the HbA1c level in the people with prediabetic glycaemic status as well as in normal glycaemic status but does not affect fasting plasma glucose and HbA1c level in diabetic people. This finding again supports the finding by Ford et al. and Madhu et al. that the HbA1c level in the diagnostic threshold is affected by IDA [14,16]. Similarly, a case-control study by Christy et al. was conducted in 2013 on 120 diabetic patients and found a positive correlation between HbA1c and IDA (6.8+/-1.4\%), especially in women (7.02+/-1.58\%) [21]. The value of HbA1c was higher in patients with plasma fasting glucose $100-126 \mathrm{mg} / \mathrm{dl}$ $(7.33+/-1.55 \%)$ compared to euglycemic. However, there is a negative correlation between ferritin and hemoglobin. So, the author suggests the correction of IDA in a patient with impaired glycaemic control.

Some studies tried to delineate the impact of $\mathrm{Hb}$ level on HbA1c. One such study conducted by Silva et al. showed among 122 participants (67 with anemia, 67 without anemia) has found that the HbA1c level does not vary significantly with the measuring technique (like high-performance liquid chromatography (HPLC) method and immunoturbidimetry method; $\mathrm{P}=0.192$ ) [19]. Mild anemia has little impact on the HbA1c level, whereas moderate to severe anemia can increase the level of HbA1c. Hence, in people with mild anemia, HbA1c can be used as a diagnostic tool for diabetes. Others have tried to study the impact of IDA on the HbA1c level in particular settings. A study conducted by Inada and Koga in 2017 compared the HbA1c level in gastrectomized subjects with and without IDA [17]. HbA1c level showed a negative correlation with all the indicators of iron deficiency like ferritin, mean corpuscular haemoglobin (MCH), and haemoglobin. Thus, the HbA1c level is higher in gastrectomized subjects with IDA than non-IDA ( $\mathrm{P}=0.003)$.

Guo et al. in 2019 highlights the need for further studies as there is no clear cut demarcation of effects of IDA on HbA1c level; the cause being multifactorial and the effect being multidimensional [6]. Moreover, due to the lack of standard calibration method to measure HbA1c, other confounding variables like IDA may lead to misdiagnosis or underdiagnosis of diabetes. Also, a review by Naquash and Bader in his article mention that the HbA1c level is dependent on erythrocyte turnover so, in the IDA, HbA1c level increased and in other forms of anemia, HbA1c level is lowered [23]. Furthermore, other studies contradicted the finding. However, the clinical data is insufficient, and further studies are mandatory in delineating the effect of erythrocyte indices in the HbA1c level.

Similarly, a systematic review by English et al. in 2015 concludes that erythrocyte indices are essential confounders in the analysis of HbA1c in patients with anemia and diabetes [7]. So, the author highlighted the need for further study in this regard. In a review by Weykamp in 2013 [5], in anemia due to chronic disease, HbA1c is low due to decreased RBC survival, but in IDA, it is spuriously high, which is assumed to be enticed to altered glycation rate. A similar recommendation by Ahmad and Raft in 2013 suggested more research is needed to know the mechanism by which $\mathrm{Hb}$ and $\mathrm{HbA1c}$ are related precisely [24]. Furthermore, the author also recommends people who are in the diagnostic threshold to diagnose diabetes in anemia should have another method of diagnostic modality to confirm the disease.

In a nutshell, most of the studies showed a relationship between anemia and the HbA1c level; however, it fails to demonstrate the effect and the goal of optimal HbA1c control in diabetes and non-diabetes.

\section{Study limitations}

Data might not have been consistent as we included studies from all around the world. Also, we could not do the systematic review and meta-analysis of all the articles which would strengthen our paper. Furthermore, since we could review only the articles published in the English language, we might have missed the valuable findings observed in the articles published in the local languages. Besides, we reviewed the articles published since 2011 only which could have excluded the important conclusions from the articles published earlier. 


\section{Conclusions}

Our study indicates the need for screening for the anemia in patients before commencing the treatment of diabetes diagnosed via the HbA1c level. Furthermore, anemia should be corrected before setting the treatment goal of optimal HbA1c control, especially when the level is in the diagnostic threshold. Also, the purpose of strict HbA1c control is not recommended in the anemic patient before it is corrected. However, further large-scale interventional studies are needed to know precisely, the goal of optimal HbA1c control in diabetic and non-diabetic individuals.

\section{Additional Information \\ Disclosures}

Conflicts of interest: In compliance with the ICMJE uniform disclosure form, all authors declare the following: Payment/services info: All authors have declared that no financial support was received from any organization for the submitted work. Financial relationships: All authors have declared that they have no financial relationships at present or within the previous three years with any organizations that might have an interest in the submitted work. Other relationships: All authors have declared that there are no other relationships or activities that could appear to have influenced the submitted work.

\section{Acknowledgements}

We would like to heartily acknowledge Dr. Sushma Khadka (Internal Medicine, National Academy of Medical Sciences (NAMS) Bir hospital, Nepal) for constant motivation and support throughout the article writing and recognize "Microsoft Word" and "Mendeley Desktop" for providing a platform for this article. Our sincere gratitude for California Institute of Behavioral Neuroscience \& Psychology for proper guidance.

\section{References}

1. Khusun H, Yip R, Schultink W, Dillon DHS: World Health Organization hemoglobin cut-off points for the detection of anemia are valid for an Indonesian population. J Nutr. 1999, 129:1669-1674. 10.1093/jn/129.9.1669

2. Chaparro CM, Suchdev PS: Anemia epidemiology, pathophysiology, and etiology in low- and middle-income countries. Ann N Y Acad Sci. 2019, 1450:15-31. 10.1111/nyas.14092

3. Forouhi NG, Wareham NJ: Epidemiology of diabetes. Medicine. 2014, 42:698-702. 10.1016/j.mpmed.2014.09.007

4. American Diabetes Association: Classification and diagnosis of diabetes: Standard of Medical Care in Diabetes-2020. Diabetes Care. 2020, 43:S14-S31. 10.2337/dc20-S002

5. Weykamp C: HbA1c: a review of analytical and clinical aspects . Ann Lab Med . 2013, 33:393-400. 10.3343/alm.2013.33.6.393

6. Guo W, Zhou Q, Jia Y, Xu J: Increased levels of glycated hemoglobin A1c and iron deficiency anemia: a review. Med Sci Monit. 2019, 25:8371-8378. 10.12659/MSM.916719

7. English E, Idris I, Smith G, Dhatariya K, Kilpatrick ES, John WG: The effect of anaemia and abnormalities of erythrocyte indices on HbA1c analysis: a systematic review. Diabetologia . 2015, 58:1409-1421. 10.1007/s00125-015-3599-3

8. Florkowski C: HbA1c as a diagnostic test for diabetes mellitus - reviewing the evidence . Clin Biochem Rev . 2013, 34:75-83.

9. Horton BF, Huisman TH: Studies on the heterogeneity of haemoglobin. VII. Minor haemoglobin components in haematological diseases. Br J Haematol. 1965, 11:296-304. 10.1111/j.13652141.1965.tb06589.x

10. Solomon A, Hussein M, Negash M, Ahmed A, Bekele F, Kahase D: Effect of iron deficiency anemia on HbA1c in diabetic patients at Tikur Anbessa specialized teaching hospital, Addis Ababa Ethiopia. BMC Hematol. 2019, 19:2. 10.1186/s12878-018-0132-1

11. Kalairajan S, Durairaj KV, Malathy AR: A study on influence of iron deficiency anaemia over HbA1c levels . Int J Adv Med. 2019, 6:2349-3933. 10.18203/2349-3933.ijam20192586

12. Alsayegh F, Waheedi M, Bayoud T, Al Hubail A, Al-Refaei F, Sharma P: Anemia in diabetes: experience of a single treatment center in Kuwait. Prim Care Diabetes. 2017, 11:383-388. 10.1016/j.pcd.2017.04.002

13. Villar E, Lièvre M, Kessler M, et al.: Anemia normalization in patients with type 2 diabetes and chronic kidney disease: results of the NEPHRODIAB2 randomized trial. J Diabetes Complications. 2011, 25:237-243. 10.1016/j.jdiacomp.2011.03.003

14. Ford ES, Cowie CC, Li C, Handelsman Y, Bloomgarden ZT: Iron-deficiency anemia, non-iron-deficiency anemia and HbA1c among adults in the US. J Diabetes. 2011, 3:67-73. 10.1111/j.1753-0407.2010.00100.x

15. Urrechaga E: Influence of iron deficiency on Hb A1c levels in type 2 diabetic patients . Diabetes Metab Syndr. 2018, 12:1051-1055. 10.1016/j.dsx.2018.06.024

16. Madhu SV, Raj A, Gupta S, Giri S, Rusia U: Effect of iron deficiency anemia and iron supplementation on HbA1c levels - implications for diagnosis of prediabetes and diabetes mellitus in Asian Indians. Clin Chim Acta. 2017, 468:225-229. 10.1016/j.cca.2016.10.003

17. Inada S, Koga M: HbA1c and glycated albumin levels are high in gastrectomized subjects with irondeficiency anemia. Ann Clin Lab Sci. 2017, 47:52-57.

18. Esfahani E, Larijani B, Amini P, Ghodssi-Ghassemabadi R, Razmandeh R: Effect of treatment of iron deficiency anemia onhemoglobin A1c in type 2 diabetic patients. Turkish J Med Sci. 2017, 47:1441-1446. 10.3906/sag-1601-27

19. Silva JF, Pimentel AL, Camargo JL: Effect of iron deficiency anaemia on HbA1c levels is dependent on the 


\section{Cureus}

degree of anaemia. Clin Biochem. 2016, 49:117-120. 10.1016/j.clinbiochem.2015.09.004

20. Hong JW, Ku CR, Noh JH, Ko KS, Rhee BD, Kim D-J: Association between the presence of iron deficiency anemia and hemoglobin A1c in Korean adults: the 2011-2012 Korea National Health and Nutrition Examination Survey. Medicine. 2015, 94:e825. 10.1097/MD.0000000000000825

21. Christy AL, Manjrekar PA, Babu RP, Hegde A, Rukmini MS: Influence of iron deficiency anemia on hemoglobin A1c levels in diabetic individuals with controlled plasma glucose levels. Iran Biomed J. 2014, 18:88-93.

22. Shanthi B, Revathy C, Manjula Devi AJ, Subhashree: Effect of iron deficiency on glycation of haemoglobin in nondiabetics. J Clin Diagn Res. 2013, 7:15-17. 10.7860/JCDR/2012/4881.2659

23. Naqash A, Bader GN: Influence of iron deficiency anemia on HbA1c: a review . Curr Res Diabetes Obes J. 2018, 5:555665. 10.19080/CRDOJ.2018.05.555665

24. Ahmad J, Rafat D: HbA1c and iron deficiency: a review. Diabetes Metab Syndr. 2013, 7:118-122. 10.1016/j.dsx.2013.02.004 